\title{
Tuberkulosis diseminata pada kehamilan
}

\author{
Yanrike Harahap ${ }^{1}$, Fauzar ${ }^{2}$ \\ 1. Program Studi Pendidikan Dokter Spesialis, Fakultas Kedokteran, Universitas Andalas; 2. Bagian \\ Ilmu Penyakit Dalam, RSUP dr. M. Djamil Padang
}

Korespondensi: Yanrike Harahap; email: yanrike hrp@yahoo.com

\begin{abstract}
Abstrak
Tuberkulosis merupakan penyakit infeksi yang banyak dijumpai pada negara berkembang, bermanifestasi di berbagai organ dan menimbulkan berbagai macam tanda dan gejala. Ketepatan menegakkan diagnosa diharapkan dapat memperbaiki kualitas hidup ibu hamil dan mencegah infeksi pada janin dan bayi. Tujuan: Melaporkan tuberkulosis diseminata dalam kehamilan sebagai salah satu penyebab angka kesakitan dan kematian ibu hamil. Diagnosis dini dan penatalaksanaan segera dapat menurunkan angka morbiditas dan mortalitas. Kasus: Dilaporkan seorang perempuan 28 tahun dengan keluhan sesak nafas yang bertambah berat sejak satu minggu sebelum masuk rumah sakit, demam yang terus menerus sejak 1,5 bulan yang lalu dan hamil anak I dengan usia kehamilan 18-19 minggu. Pemeriksaan fisik ditemukan konjungtiva anemis, dyspnea dengan suara pernafasan yang normal dan hepatomegali. Pada pemeriksaan penunjang didapatkan anemia , peningkatan laju endap darah dan pada rontgen paru dengan kesan TB milier, USG abdomen dengan hepatomegali disertai kalsifikasi dan pada pemeriksaan mata ditemui adanya koroidal tuberkel. Pasien diberikan obat anti tuberkulosis kategori I dan kortikosteroid dan mengalami perbaikan. Simpulan: Sangat penting untuk mendiagnosis adanya infeksi TB secara dini pada wanita hamil. Penatalaksanaan TB pada kehamilan sama seperti TB pada umumnya. Jika terjadi kehamilan pada saat menderita TB maka tidak dianjurkan untuk menggugurkan kandungannya kecuali atas indikasi obstetri.
\end{abstract}

Kata kunci: tuberkulosis diseminata; tuberkulosis milier; kehamilan

\section{Abstract}

Tuberculosis is an infectious disease found in developing countries, manifests in various organs which caused variety of signs and symptoms. Accuracy in establishing the diagnosis is to improve the quality of life of pregnant women and to prevent infection of fetus. Objective: To report a case of disseminated tuberculosis in pregnancy as one of the causes of morbidity and mortality in pregnancy. Early diagnosis and prompt management is needed. Case: Reported a 28-year-old woman with complaint of breathlessness that increased since one week before being admitted to the hospital, continuous fever since 1.5 months ago and first pregnancy with gestational age 18-19 weeks. Physical examination found anemic conjunctiva, dyspnea with normal respiratory sound and hepatomegaly. Further investigation found anemia, increase in rate of blood sedimentation, appearance of miliary TB, hepatomegaly accompanied by calcification and from funduscopy found choroidal tubercles. Patient is given anti-tuberculosis drugs category I and corticosteroid with good outcome. Conclusion: It is very important to do an early detection of $T B$ infection in pregnant women. The management of $T B$ in pregnancy is the same as TB in general. Pregnant women with tuberculosis are not recommended to undergo abortion except for obstetric indication.

Keywords: disseminated tuberculosis; miliary tuberculosis; pregnancy 


\section{PENDAHULUAN}

Tuberkulosis (TB) adalah suatu penyakit yang disebabkan oleh Mycobacterium tuberculosis, sejenis kuman yang berbentuk batang, dan sebagian besar lebih tahan asam dan tahan terhadap trauma fisik dan kimia. TB diseminata adalah suatu keadaan dimana ditemukannya isolasi TB pada dua organ atau lebih yang disebabkan oleh kuman Mycobacterium tuberculosis yang menyebar secara limfohematogenus. ${ }^{1}$ TB milier adalah bentuk tuberkulosis yang ditandai dengan penyebaran luas ke dalam tubuh manusia dengan ukuran lesi kecil (1$5 \mathrm{~mm}$ ). Namanya berasal dari pola yang khas yang terlihat pada rontgen dada berupa gambaran banyak bintik-bintik kecil yang didistribusikan secara merata ke seluruh bagian paru-paru dengan tampilan yang mirip biji milet sehingga disebut sebagai TB milier. ${ }^{2}$

Insiden kematian akibat tuberkulosis menurut WHO mengalami penurunan sebanyak 22\% antara tahun 2000 dan 2015, namun TB masih menempati peringkat ke-10 penyebab kematian tertinggi di dunia tahun 2016. Oleh sebab itu hingga saat ini TB masih menjadi prioritas utama di dunia dan menjadi salah satu tujuan dalam SDGs (Sustainability Development Goals) tahun 2010 berjumlah 430.000 kasus per tahun. ${ }^{3}$ Secara global, TB sendiri merupakan penyakit infeksi terbanyak ketiga yang menyebabkan peningkatan angka kesakitan dan angka kematian pada wanita usia 15-44 tahun sehingga memberikan kontribusi yang signifikan terhadap angka kematian ibu. Pada negara berkembang terjadi peningkatan angka kejadian tuberkulosis pada wanita dalam kehamilan. Hal ini dikatakan sebagai akibat dari peningkatan angka kejadian tuberkulosis pada usia muda dan pada etnis minoritas dan pendatang. ${ }^{4}$ Insiden tuberkulosis dalam kehamilan adalah 1/10.000 kehamilan. Pada tahun 1997-2001 terdapat insiden kejadian TB 252/100.000 kelahiran. 53\% di diagnosa sebagai TB ekstrapulmonar, 38\% TB pulmonal dan 9\% TB ekstra dan Intra pulmonal. ${ }^{5}$ Frekuensi wanita hamil dengan TB di Indonesia adalah 1,6\%. Angka kekerapan yang pasti belum ada tetapi dari gambaran persalinan di RSCM tahun 19981999 dari 4300 persalinan, terdapat 150 orang yang didiagnosis sebagai TB $(3,48 \%) .^{5}$

Tuberkulosis dalam kehamilan mempunyai gejala klinis yang serupa dengan TB pada wanita yang tidak hamil dan diagnosis mungkin terlambat ditegakkan karena manifestasi yang tidak khas, tertutup oleh gejala-gejala dalam kehamilan. ${ }^{6}$ Sehingga penegakan diagnosa tuberkulosis dalam kehamilan merupakan suatu tantangan tersendiri. Penurunan berat badan pada TB tertutupi dengan berat badan normal karena kehamilan dan keluhan lainnya dihubungkan dengan kehamilan juga. ${ }^{7}$

Diagnosis ditegakkan berdasarkan anamnesis, pemeriksaan fisik dan pemeriksaan penunjang. Gejala klinis tuberkulosis pada kehamilan dapat berupa batuk (74\%), penurunan berat badan (74\%), demam (30\%), nafsu makan yang 
menurun (30\%) dan adanya batuk disertai darah (19\%). Sebagian besar tuberkulosis dalam kehamilan sering kali tanpa gejala yang khas, maka sekitar $30 \%$ ibu terdiagnosis tuberkulosis setelah bayi yang dilahirkan menderita tuberkulosis kongenital. TB paru merupakan manifestasi klinis yang paling sering dibandingkan dengan organ lain. Pada TB kulit atau jaringan lunak, penularan bisa melalui inokulasi langsung. ${ }^{8}$

Pada pemeriksaan fisik ditemukan suara nafas tambahan berupa ronki basah, kasar dan nyaring dari auskultasi. Pada pemeriksaan penunjang laboratorium darah didapatkan leukositosis, limfosit di bawah normal dan LED yang meningkat. Pada pemeriksaan sputum jika ditemukan kuman basil tahan asam maka diagnosa tuberkulosis sudah dapat dipastikan. Selain sebagai salah satu cara kriteria penegakan diagnosa juga dapat dijadikan sebagai evaluasi terhadap pengobatan yang diberikan. World Health Organization (WHO) merekomendasikan pemeriksaan cepat untuk mendiagnosis TB paru dengan menggunakan alat Xpert MTB/RIF, sebuah tes molekuler untuk Mycobacterium tuberculosis (MTB) dan resisten Rifampisin (RIF) dengan menggunakan sampel dari dahak dalam waktu dua jam. ${ }^{8}$

Pada pemeriksaan radiologi tuberkulosis milier ditemukan bercak halus yang umumnya tersebar merata pada seluruh lapangan paru. Akibat penyebaran hematogen tampak sarang sekecil 1-2 mm atau sebesar kepala jarum (milium), tersebar merata di kedua belah paru.
Gambaran ini dikenal dengan gambaran "badai kabut" atau snow storm appearance. Penyebaran ini dapat juga terjadi ke ginjal, tulang, sendi, selaput otak (meningen) dan sebagainya. ${ }^{9}$

Penatalaksanaan penyakit ini diberikan obat anti tuberkulosis sama seperti pada TB paru dan pada keadaan khusus, tergantung klinis dan evaluasi pengobatan.6 Pemberian kortikosteroid bermanfaat pada pasien dengan meningitis tuberkulosis, perikarditis tuberkulosis dan tuberkulosis milier dengan hipoksemia refrakter, dimana kortikosteroid dihubungkan dengan penurunan angka kematian, dan kecilnya angka kejadian perikardiosintesis atau perikardiektomi. $^{1}$

\section{LAPORAN KASUS}

Seorang pasien perempuan usia 28 tahun dirawat di Bangsal Penyakit Dalam RSUP dr. M. Djamil Padang dengan keluhan utama sesak nafas yang meningkat sejak 1 minggu sebelum masuk rumah sakit. Sebelumnya sesak dirasakan terus menerus sejak 1 bulan yang lalu tidak dipengaruhi oleh aktivitas dan cuaca. Demam terus menerus sejak 1,5 bulan yang lalu tetapi tidak terlalu tinggi dan tidak menggigil. Batuk sejak 1 bulan yang lalu berdahak dan tidak berdarah. Berkeringat banyak terutama pada malam hari semenjak 1 bulan yang lalu. Mengalami penurunan berat badan sebanyak $3 \mathrm{~kg}$ dalam 1 bulan terakhir dan nafsu makan yang menurun semenjak 15 hari yang lalu disertai pucat yang baru 
disadari pasien sejak 15 hari yang lalu. Pasien sebelumnya telah dirawat di RSUD Painan selama 4 hari dan dirujuk ke RSUP $M$ Djamil padang untuk penelusuran lebih lanjut. Pasien saat ini sedang hamil anak pertama dan tidak ada riwayat sex bebas, pemakaian jarum suntik bergantian dan tato. Riwayat imunisasi sewaktu kecil tidak lengkap. Pada pemeriksaan fisik didapatkan denyut nadi $110 x /$ menit, frekuensi nafas 25 kali per menit, body mass index 17,9. Konjungtiva anemis. Pemeriksaan fisik paru dan jantung yang normal. Pada pemeriksaan fisik abdomen ditemukan hepatomegali. Pada pemeriksaan laboratorium didapatkan $\mathrm{Hb}$ $8,4 \mathrm{~g} / \mathrm{dL}$, leukosit $12.100 / \mathrm{mm}^{3}$, Ht $26 \%$, Trombosit $127.100 / \mathrm{mm}^{3}$, hitung jenis 0/0/0/90/8/2, Laju endap darah (LED) 35 $\mathrm{mm} / \mathrm{jam}$. Pada gambaran darah tepi didapatkan anemia mikrositik hipokrom, leukosit jumlah meningkat dan trombosit jumlah kurang morfologi normal. Analisa gas darah didapati kesan alkalosis metabolik.

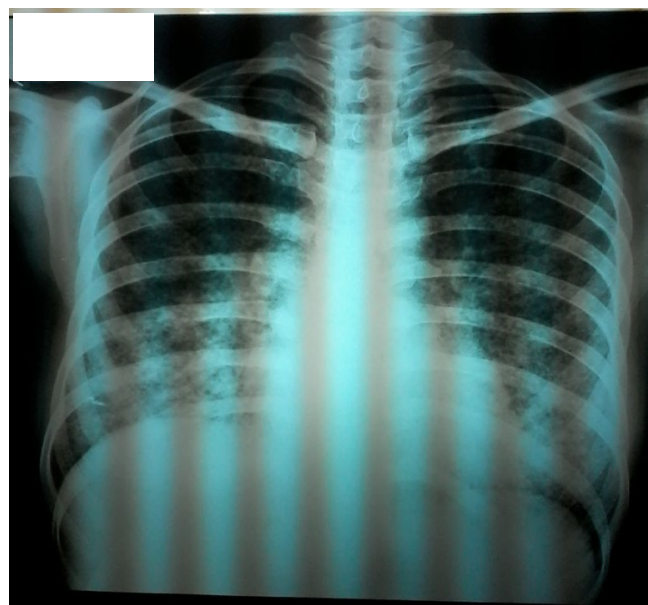

Gambar 1. Rontgen dada terlihat snow storm appearance.

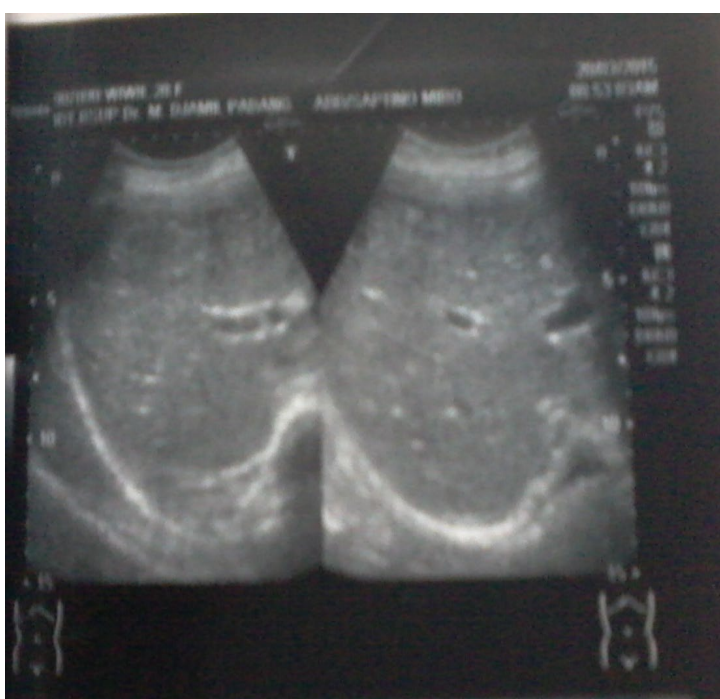

Gambar 2. Gambaran USG Hepar terdapat kalsifikasi hepar ringan

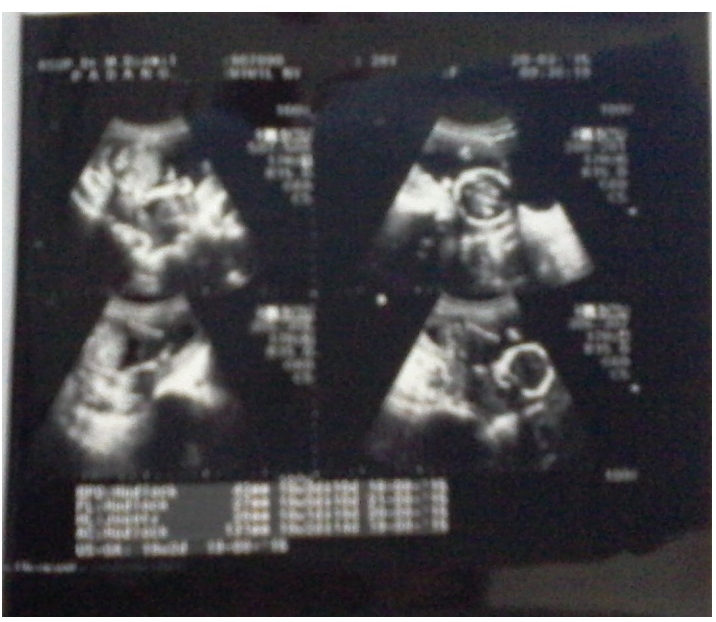

Gambar 3. USG Fetomaternal dengan kesan janin hidup grafid 18-19 minggu

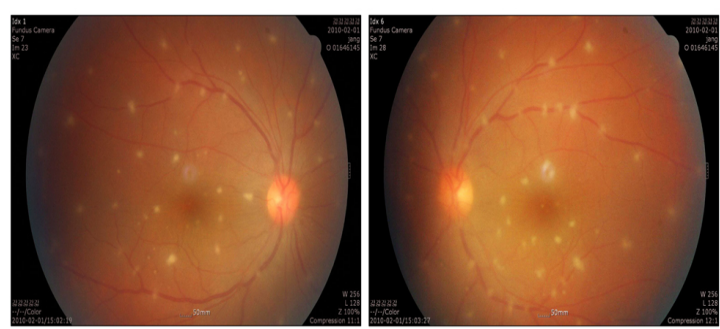

Gambar 4. Khoroidal tuberkel

Pemeriksaan BTA dan Rapid Test HIV negatif. Pada pemeriksaan Ekokardiografi (EKG) ditemukan normal EKG. Pada pemeriksaan rontgen dada ditemukan snow storm appearance. Pemeriksaan 
ultrasonografi (USG) abdomen didapatkan kalsifikasi hepar ringan, pemeriksaan USG fetomaternal dengan kesan Gravid 18-19 minggu tunggal janin hidup. Pada pemeriksaan funduskopi pada mata ditemukan choroidal tuberkel.

\section{PEMBAHASAN}

Pasien seorang wanita usia muda dengan kehamilan anak I, sehingga penegakan diagnosa dan terapi yang cepat dan tepat sangat penting. Tuberkulosis dalam kehamilan mempunyai gejala yang sama dengan tuberkulosis tanpa kehamilan. Diagnosa tuberkulosis mungkin terlambat ditegakkan karena gejala awal yang tidak khas. Penegakan diagnosa pada wanita hamil memiliki langkah yang sama dengan tuberkulosis tanpa kehamilan. Pasien ini merupakan wanita hamil dengan kehamilan telah melewati trimester I dan telah dilakukan pemeriksaan rontgen dada di RSUD. Rontgen dada pada wanita hamil diperlukan jika pasien tidak mampu untuk mengeluarkan sputum, atau hasil pemeriksaan basil tahan asam (BTA) langsung memberikan nilai negatif (tidak ditemukan BTA). Pemeriksaan radiologi harus memakai pelindung timah pada abdomen sehingga bahaya radiasi terhadap janin lebih minimal. Jika usia kehamilan masih dalam trimester pertama, sebaiknya pemeriksaan radiologi dada tidak dikerjakan karena masih bisa berdampak negatif pada sel-sel muda janin walaupun kejadiannya sedikit. Umumnya pemeriksaan radiologi dada merupakan pemeriksaan penapis yang efektif. Dengan pemeriksaan radiologi dada diagnosis TB paru lebih banyak ditemukan dibandingkan pemeriksaan bakteriologi sputum. Gambaran radiologi yang diberikan hampir sama dengan TB paru tanpa kehamilan, yakni infiltrat, kalsifikasi, fibrotik, kavitas, efusi pleura dll.6

Pemeriksaan radiologi pada pasien dalam kehamilan boleh dilakukan dengan menggunakan plat pelindung. Menurut The American Collage of Obstetricians and Gynecologist tentang Guidelines for Diagnostic Imaging During Pregnancy and Lactation 2017, pada kehamilan 16-25 minggu bisa dilakukan pemeriksaan radiologi dengan batas dosis yang bisa ditoleransi adalah 250-280 mGy. Pada pemeriksaan radiologi paru sendiri radiasi yang dihasilkan adalah 0,0005-0,01. ${ }^{10}$ Menurut The American Collage of Radiology, pada kehamilan 18-27 minggu efek radiasi di bawah 100 mGy tidak memberikan efek apa pun pada kehamilan. Peningkatan efek radiasi berada pada garis lurus sebanding dengan peningkatan dosis radiasi. Secara teoritis dikatakan bahwa peningkatan dosis radiasi menyebabkan resiko kanker sebesar $3 \%$, retardasi mental (6\%) penurunan IQ sebesar 10 poin setiap $100 \mathrm{mGy}$ dan $15 \%$ kemungkinan terjadinya mikrosefalia. Tetapi bagaimanapun juga risiko yang terjadi tergantung kepada lamanya paparan terhadap radiasi. Walaupun demikian rata-rata besar paparan radiasi terhadap fetus kecil dari 50 mGy setiap pemeriksaan. ${ }^{11}$

Pasien ini diberikan terapi anti tuberkulosis kategori satu karena pasien ini tidak 
memiliki riwayat pengobatan tuberkulosis sebelumnya. Dengan regimen yang tepat dan adekuat maka diharapkan manifestasi klinis dan progresivitas dari penyakit tuberkulosis pada ibu hamil tidak terlalu mempengaruhi kehamilan dan sekaligus akan memperbaiki kualitas hidup ibu, mengurangi efek samping obat-obat tuberkulosis terhadap janin dan mencegah infeksi yang terjadi pada janin dan bayi yang baru lahir. Obat anti tuberkulosis yang diberikan dibagi dalam 2 golongan yaitu obat lini pertama dan lini kedua. Obat lini pertama, kecuali Streptomisin dapat digunakan pada tuberkulosis pada kehamilan. Streptomisin dikaitkan dengan kecepatannya melewati plasenta sampai ke sirkulasi janin dan cairan amnion serta mencapai kadar kurang dari 50\% di bandingkan kadar ibu dan adanya efek ototoksisitas yang bisa menyebabkan terjadinya tuli kongenital pada bayi dan beberapa penelitian juga menyebutkan adanya kerusakan nervus cranialis ke-8. Penggunaan streptomisin dan obat lini kedua (Kanamisin, Etionamid, Kapreomisin) sebaiknya dihindari pada wanita hamil karena efek samping yang akan terjadi pada janin, kecuali dalam keadaan resistensi beberapa obat. ${ }^{5}$

Pasien ini sedang dalam kondisi gravid 1819 minggu dimana pasien akan menghadapi persalinannya. Pada pasien yang sudah cukup mendapatkan pengobatan dalam masa kehamilan bisa melakukan persalinan seperti biasa, akan tetapi pada mereka yang masih aktif akan dilakukan persalinan dengan kala II dipercepat. Pada wanita TB dengan menyusui obat anti tuberkulosis (OAT) masih dapat diberikan, walaupun OAT dapat masuk ke dalam air susu ibu (ASI) tetapi konsentrasinya kecil dan tidak menyebabkan toksik pada bayi. Pada Wanita usia produktif yang mendapatkan pengobatan TB dengan Rifampicin dianjurkan untuk tidak menggunakan kontrasepsi hormonal karena dapat terjadi interaksi obat yang menyebabkan efektivitas obat kontrasepsi hormonal berkurang. ${ }^{6}$

Pasien juga dicurigai menderita TB hepar, karena dari pemeriksaan fisik ditemui adanya hepatomegali dan peningkatan fungsi hati, sedangkan pemeriksaan hepatitis marker yang dapat kita lakukan di sini menunjukkan hasil yang negatif sehingga kemudian dilakukan pemeriksaan lanjutan berupa tindakan USG Abdomen ketika keadaan pasien sudah memungkinkan dan didapatkan adanya gambaran kalsifikasi ringan pada permukaan hati. Gejala klinis yang sering ditemui pada TB hepar adalah hepatomegali, demam, nyeri perut dan penurunan berat badan. ${ }^{12}$ Adanya gambaran rontgen paru yang mendukung gambaran TB dapat membantu dalam menegakkan diagnosis, tetapi gambaran rontgen yang tidak mendukung diagnosis TB bukan berarti bisa menyingkirkan diagnosis TB hepar. Adanya pembesaran hati, nodul hati yang lebih dari satu tahun harus lebih dicurigai sebagai TB hepar dibandingkan sebagai suatu keganasan. Menurut sebuah jurnal dikatakan bahwa 
kalsifikasi hati terjadi pada $>50 \%$ kasus, kalsifikasi melibatkan kedua hati dan pada 98\% kasus memiliki kalsifikasi kecil yang tersebar dan berukuran 8-12 $\mathrm{mm}$. Kalsifikasi pada hati dapat dideteksi dini melalui USG dibandingkan dengan foto polos abdomen. Pemeriksaan selanjutnya yang dianjurkan adalah biopsi hati dengan laparoskopi dimana diagnosis dari TB hati dapat ditegakkan hampir $100 \%$ melalui biopsi hati. Pengobatan TB hati tidak berbeda dengan pengobatan TB paru tetapi memerlukan jangka waktu yang lebih lama yaitu pada umumnya 1 tahun terapi. Penggunaan obat anti tuberkulosis menunjukkan hasil yang positif dimana terjadi penurunan rasa nyeri pada perut, hilangnya demam, berkurangnya ukuran hari dan terjadi peningkatan nafsu makan dan berat badan. ${ }^{13}$

Infeksi TB paling sering ditemukan di paru, tapi tidak menutup kemungkinan keterlibatan organ lain seperti mata, otak, ginjal, usus dan tulang juga bisa terlibat. Bahkan TB merupakan penyebab uveitis tersering. Koroiditis diseminata adalah tampilan umum dengan ciri khas adanya lesi kekuningan yang tersebar dan banyak dengan diameter 0,5 sampai $3,0 \mathrm{~mm} \cdot{ }^{14}$ Kejadian TB pada mata pada pasien dengan uveitis dan TB diseminata adalah $0-0,16 \%$ dan $0,27-1,4 \% .^{15}$

Tuberkulosis di diagnosis dengan
mendapatkan
Mycobacterium tuberculosis dari spesimen pasien. ${ }^{16}$ Ditemukannya koroidal tuberkel merupakan tanda awal dari koroiditis $T B$ dan mengindikasikan adanya penyebaran secara hematogen sebelum munculnya gejala penyakit. Tuberkulosis milier merupakan salah satu faktor penyebab utama kejadian koroiditis TB. ${ }^{17}$ Penemuan Mycobacterium tuberculosis melalui metode PCR secara genomik merupakan diagnostik yang berharga. ${ }^{18}$ Keterlambatan dalam penegakan diagnosis dan pemberian terapi memberikan prognosis yang jelek dan gejala sisa yang parah. Terapi yang efektif harus dimulai secepatnya. Respon terhadap terapi bisa membantu untuk menegakkan diagnosa koroiditis TB. ${ }^{17}$

Penatalaksanaan pasien TB pada kehamilan tidak berbeda dengan TB tanpa kehamilan. Hal-hal yang harus diperhatikan adalah pemberian OAT yang bisa menimbulkan efek teratogenik terhadap janin. Penatalaksanaan secara umum terbagi atas penderita dengan TBC aktif dan TBC laten. Wanita hamil dengan TBC aktif biasanya diterapi dengan tidak mempertimbangkan trimester kehamilan. OAT yang digunakan tidak berbeda dengan wanita yang tidak hamil. Golongan utama OAT seperti Isoniazid, Rifampicin, Etambutol digunakan secara luas pada wanita hamil. Obat-obat tersebut dapat melalui plasenta dalam dosis rendah dan tidak menimbulkan efek teratogenik pada janin. Pada pemberian Isoniazid sebaiknya diberikan Piridoksin 50 mg/hari untuk mencegah terjadinya neuropati perifer. Pemeriksaan fungsi hati sebaiknya dilakukan saat pemberian Isoniazid dan Rifampicin. Pemberian vitamin K dilakukan pada akhir trimester ketiga kehamilan dan 
bayi yang baru lahir. Penggunaan streptomisin dan obat lini kedua dihindari pada pasien hamil karena efek samping terhadap janin, kecuali dalam keadaan Multi Drug Resistance (MDR). ${ }^{5}$

Pasien yang sudah cukup mendapat pengobatan selama kehamilan biasanya masuk ke dalam persalinan dengan proses tuberkulosis yang sudah tenang. Persalinan pada wanita yang tidak mendapat pengobatan dan tidak aktif lagi, dapat berlangsung seperti biasa, akan tetapi pada mereka yang masih aktif, penderita ditempatkan dikamar bersalin tertentu (tidak banyak digunakan penderita lain). Persalinan ditolong dengan kala II dipercepat misalnya dengan tindakan ekstraksi vakum atau forsep, dan sedapat mungkin penderita tidak mengedan, diberi masker untuk menutupi mulut dan hidungnya agar tidak terjadi penyebaran kuman ke sekitarnya. Sedapat mungkin persalinan berlangsung per vaginam. Sedangkan sectio caesarea hanya dilakukan atas indikasi obstetri dan tidak atas indikasi tuberkulosis paru. ${ }^{6}$

Jangan pisahkan anak dari ibunya kecuali ibu sakit sangat parah. Apabila dahak ibu negatif, segera berikan BCG pada bayi, tetapi jika positif selama kehamilan dan masih tetap positif saat melahirkan maka jika bayi tampak sakit dan dicurigai menderita TB kongenital berilah pengobatan anti TB yang lengkap. Tetapi jila anak tampak sehat, berikan Isoniazid 5 $\mathrm{mg} / \mathrm{kgBB}$ dalam dosis tunggal selama 2 bulan, kemudian lakukan tes tuberkulin, jika negatif hentikan Isoniazid dan berikan BCG tetapi jika positif, lanjutkan Isoniazid selama 4 bulan lagi. Tidak ada kontraindikasi untuk menyusui pada ibu yang menderita tuberkulosis, walaupun obat anti tuberkulosis ditemukan pada air susu ibu tetapi jumlahnya sangat rendah dan risiko keracunan pada bayi sangat minimal. Pasien hanya perlu diinstruksikan agar menutup mulut saat batuk dan saat menyusui. ${ }^{6}$ Sampai saat ini tidak ada konsensus yang mengatakan dengan pasti berapa jumlah vaksin BCG yang diberikan, kapan pemberian vaksin BCG dan interpretasi hasil vaksin BCG pada bayi dengan wanita yang terinfeksi TB. ${ }^{19}$

Ikatan batin antara ibu dan anak sangat penting dan pemberian air susu ibu memainkan peranan penting dalam membentuk kekebalan pada bayi pada awal kehidupan. Sehingga diperlukan pemeriksaan yang cermat untuk memastikan bahwa ibu dan bayi bisa bersama atau jika tidak bisa dihindari maka ibu dan bayi dipisahkan. Pemberian air susu ibu bukan merupakan suatu kontra indikasi pada ibu yang menderita TB aktif atau TB laten dengan OAT lini pertama. Bayi sebaiknya diberikan Piridoksin jika ibu mendapatkan Isoniazid. Tetapi jika ibu mendapatkan Rifabutin atau Fluoroquinolone maka menyusui menjadi suatu kontraindikasi. Pemisahan antara ibu dan bayi hanya dilakukan pada kondisi jika ibu dicurigai menderita TB resisten obat dan bayi tidak terinfeksi TB, sebaiknya dipisahkan sampai ibu tidak bisa menularkan. ${ }^{20}$ 


\section{SIMPULAN}

Sangat penting untuk dapat mendiagnosis adanya infeksi TB secara dini pada wanita hamil. TB pada wanita hamil dan tidak hamil memiliki prognosis yang tidak berbeda bahkan sama. Hasil yang lebih baik didapatkan jika wanita itu diketahui menderita TB sebelum masa kehamilannya. Tb milier merupakan komplikasi dari suatu fokus infeksi tuberkulosis yang disebarkan secara hematogen bersifat sistemik. TB dalam kehamilan sendiri hanya terjadi pada 1/10.000 kehamilan tetapi lebih sering ditemukan pada pasien imunodefisiensi sedangkan pada pasien ini tidak. Penatalaksanaan pada TB pada kehamilan ini sama seperti TB paru pada umumnya. Jika terjadi kehamilan pada saat menderita TB maka tidak dilanjutkan untuk menggugurkan kandungannya kecuali atas indikasi obstetri.

\section{DAFTAR PUSTAKA}

1. Ribeiro S, Trabulo D, Cardoso C, Oliveira A, Cremers I, Disseminated Tuberculosis in an Immunocompetent Patient: The Answer is in the Liver. GE Port J Gastroenterol. 2016; 23(4):208213. doi: $10.1016 / j . j p g e .2015 .10 .002$. [PMC free article].

2. Fitzgerald DW, Sterling TR, Haas DW. Mycobacterium tuberculosis. Dalam: Bennett JE, Dolin R, Blaser MJ, editors. Mandell, Douglas, and Bennett's Principles and Practice of Infectius Diseases Volume 2. Philadelphia: Saunders; 2015. p.2787-818. doi: 10.1016/C2012-1-00075-6.

3. Mathad JS, Gupta A. Tuberculosis in pregnant and postpartum women: epidemiology, management, and research gaps. Clin Infect Dis. 2012; 55(11):1532-49. doi: 10.1093/cid/cis732. [PubMed]

4. Zenner D, Kruijshaar ME, Andrews N, Abubakar I. Risk of tuberculosis in pregnancy: a national, primary care-based cohort and self-controlled case series study. Am J Respir Crit Care Med. 2012; 185(7):779-84. doi: 10.1164/rccm.201106-10830C. [PubMed].

5. Meiyanti. Penatalaksanaan tuberkulosis pada kehamilan. Universa medicina. 2007; 26(3):143-51. [Abstract/Free Full-Text].

6. Shandera $W X$, Merchant $O$. The inconsistent definitions used for tuberculosis in the medical literature. International Journal of Mycobacteriology. 2015; 4(2):158-60. doi: 10.1016/j.ijmyco.2015.03.001.

7. Loto OM, Awowole I. Tuberculosis in pregnancy: a review. J Pregnancy. 2012; 2012:379271. doi: 10.1155/2012/379271. [PubMed].

8. Yusuf A, Merry IS. Penatalaksanaan Kehamilan dengan Tuberkulosis Paru. J Agromedicine Unila. 2018; 5(2):622-26. [Abstract/Free Full-Text].

9. Vallejo JG, Starke JR. Tuberculosis and pregnancy. Clin Chest Med. 1992;13(4):693-707. [PubMed].

10. Bates M, Ahmed Y, Kapata N, Maeurer M, Mwaba P, Zumla A. Perspectives on tuberculosis in pregnancy. Int J Infect Dis. 2015; 32:124-7. doi: 10.1016/i.ijid.2014.12.014. [PubMed]. 
11. Wieseler KM, Bhargava P, Kanal KM, Vaidya S, Steward BK, Dighe MK. Imaging in pregnant patients: examination appropriateness. Radiographics. 2010; 30(5):1215-29. doi: 10.1148/rg.305105034. [PubMed].

12. Hickey AJ, Gounder L, Moosa MY, Drain PK. A systematic review of hepatic tuberculosis with considerations in human immunodeficiency virus co-infection. BMC Infect Dis. 2015; 15:209. doi: 10.1186/s12879-015-0944-6. [PubMed].

13. Alvarez SZ. Hepatobiliary tuberculosis. J Gastroenterol Hepatol. 1998;13(8):833-9. doi: 10.1111/j.1440-1746.1998.tb00743.x. [PubMed].

14. Mohammadi N, Ghassemi F, Shojaei P, Moradnejad P. Bilateral Presume Tuberculous Choroiditis. J Ophthalmic Vis Res. 2016; 11(2):228-230. doi: 10.4103/2008-322X.183927. [PMC free article].

15. Akal A, Goncu T, Boyaci FN, Sak ZHA, Yalcin F, Ozkan U, et al. Primary Tubercular Chorioretinitis. Ann Med Health Sci Res. 2014; 4(6):965-967. doi: 10.4103/2141-9248.144928. [PMC free article].

16. Znaor L, Medic A, Karaman K, Perkovic D. Serpiginous-like choroiditis as sign of intraocular tuberculosis. Med Sci Monit. 2011; 17(7):CS88-CS90. doi: 10.12659/MSM.881839. [PMC free article].

17. Annamalai R, Biswas J. Bilateral choroidal tuberculoma in miliary tuberculosis - report of a case. J Ophthalmic Inflamm Infect. 2015; 5:4. doi: 10.1186/s12348-014-0032-x. [PMC free article].

18. Marback EF, Mendes SE, Oliveira C, Parikh JG, Rao NA . Isolated uveal tuberculoma masquerading as an intraocular tumor in an immunocompetent patient-a clinical-pathologic study with diagnosis by PCR. J Ophthalmic Inflamm Infect. 2011; 1(2):81-84. doi: 10.1007/s12348-010-0010x. [PMC free article].

19. Mittal H, Das S, Faridi MM. Management of newborn infant born to mother suffering from tuberculosis: current recommendations \& gaps in knowledge. Indian J Med Res. 2014; 140(1):329. [PubMed] [PMC free article].

20. Kodadhala V, Gudeta A, Zerihun A, Lewis O, Ahmed S, Gajjala J, et al. Postpartum Tuberculosis: A Diagnostic and Therapeutic Challenge. Case Rep Pulmonol. 2016; 2016:3793941. doi: 10.1155/2016/3793941. [PubMed] [PMC free article]. 